\title{
Osm „střípků“ ze světa bývalé srbochorvatštiny
}

KREJČÍ, P.: Eight Fragments from the World of Serbian, Croatian, Bosnian and Montenegrin Languages: Selected South Slavonic Studies 1. Brno: Masaryk University, 2018, 152 p., ISBN 978-80-210-8991-4.

Brněnský balkanista Pavel Krejčí, který dlouhodobě bádá především na poli srovnávací česko-jihoslovanské frazeologie (viz např. kniha Srbská frazeologie v českém a bulharském překladu: kontrastivní analýza, Brno 2015), se prakticky od samého počátku zabývá i historickým vývojem jednotlivých jihoslovanských spisovných jazyků, jejich standardizací a jazykovou politikou. Svědčí o tom řada studií, které publikoval $\mathrm{v}$ různých, především českých, srbských a bulharských sbornících a časopisech. Ty podstatnější $\mathrm{z}$ nich, mnohé $\mathrm{v}$ aktualizované podobě, se staly oněmi „stř́pky" tvořícími anglicky psanou monografii Eight Fragments from the World of Serbian, Croatian, Bosnian and Montenegrin Languages s upřesňujícím a současně slibujícím podtitulem Selected South Slavonic Studies 1. Už v úvodu se totiž autor zavazuje, že by tuto monografii měla $\mathrm{v}$ budoucnu následovat další, zaměřená ovšem na vybrané problémy z oblasti frazeologie a frazeografie, lexikografie a onomastiky (viz Introduction).

Osm kapitol monografie otevírají úvodní informace o jihoslovanských jazycích (South Slavonic Languages [General Overview] - s.9-27), které je zasazují do slovanského kontextu, podávají základní přehled o jejich klasifikaci, hláskové a mluvnické stavbě a v přehledu nechybí ani zmínka o různých písmech (hlaholici, cyrilici a jejích derivátech, řeckém písmu, arebici a samozřejmě latince), která se jak v minulosti, tak i v současnosti používají pro záznam jihoslovanských jazyků. Další kapitoly jsou už věnovány výhradně problematice srbochorvatštiny, resp. srbštiny, chorvatštiny, bosenštiny a černohorštiny. Tu nahliží autor z více pohledů.

Kapitola Selected Czech Handbooks of Serbo-Croatian from 6os, 7os and 8os (Sociolinguistic Analysis) (s. 29-42) se zabývá problematikou didaktiky srbochorvatštiny v 60., 70. a 80. letech minulého století. Autor na základě analýzy vybraných učebnic, konverzačních příruček, mluvnic a slovníků zkoumá, jak se v těchto př́ručkách pro českého uživatele prezentovala sociolingvistická situace v tehdejší Jugoslávii, resp. v její centrální, srbochorvatsky hovořící části (v Srbsku, Chorvatsku, Bosně a Hercegovině a Černé Hoře). Analyzuje, jak je přistupováno $k$ faktu, že srbochorvatština byla v té době oficiálně jazyk pluricentrický, se dvěma spisovnými variantami (ekavskou a ijekavskou) a dvěma rovnoprávnými grafickými systémy (latinkou a cyrilicí). Konstatuje preference ekavské varianty tehdejší srbochorvatštiny a latinky a zaznamenává i skutečnost, že autoři prakticky všech příruček si celou složitou 
sociolingvistickou situaci zjednodušili do binárního vztahu srbsko-chorvatského, takže „from the modern-day perspective interfering with the content of teaching texts in particular may be seen as the marginalization or even disregard for the Montenegrins and Bosniaks (at that time Muslims), who are practically not mentioned in the introductory chapters, or the in the actual texts that follow. The only didactical interest that we saw in the specific lexicon present in the language of the Yugoslavian Muslims, no matter how slight, was in Togner's relatively comprehensive handbook " (s. 42).

V kapitole Selected Moments from the History of Serbo-Croatian ("B-C-S" Point of View) (s. 43-57) autor porovnává srbské, chorvatské a bosňácké interpretace dějinných událostí, kterými prošel jazyk dnešních Srbů, Chorvatů, Bosňáků a Černohorců. Soustředuje se na úvodní kapitoly vybraných gramatických př́ruček, v nichž se vyskytuje přehled vývoje toho kterého jazyka. $Z$ analýzy vyplývá, že čím více se autoři $\mathrm{v}$ popisu dějinného vývoje blíží současnosti, tím více dochází $\mathrm{k}$ divergenci interpretací toho, co se vlastně stalo. Dobře patrné je to např́klad na popisu tzv. vídeňské literární dohody (s. 52-54) nebo sociolingvistické situace v období socialistické Jugoslávie (s. 54-56).

Ve čtvrté kapitole Selected Interpretations of Vuk Stefanović Karadžićs Work ("C-S" Point of View) (s. 59-66) se P. Krejčí opět zaměřuje na rozdílné interpretace - tentokrát díla nejvýznamnějšího reformátora spisovné srbštiny V. S. Karadžiće. Autor se v této kapitole soustředil na různé, často protichůdné kvalifikace, podle nichž je Karadžić vřelý srbský vlastenec a reformátor, kterého vždy zajímal jen jazyk Srbů, takže mu nelze připisovat serbokroatistické záměry, s těmi přišel až chorvatský slavista Vatroslav Jagić, jak tvrdí srbští nacionalisticky orientovaní lingvisté (s. 61-63), zatímco podle chorvatských nacionalisticky orientovaných lingvistů je Karadžić strůjcem serbokroatismu, který měl posloužit jako instrument protichorvatsky namířené velkosrbské politiky (s. 64).

Druhá polovina knihy začíná nejrozsáhlejší kapitolou nazvanou Selected South Slavonic Languages and Their Reflection in the Relevant Constitutional Articles on Language (Overview of the Language Policy in the Area of so-called Central South Slavonic Diasystem) (s. 67-103). Autor zde sleduje dynamiku lingvonym obsažených v ústavních článcích Jugoslávie od jejího založení do jejího hořkého konce (1918-1992) i v ústavách jejích čtyř „srbochorvatských“ svazových republik (1946-1990). Sonduje však i stav před rokem 1918 a provádí též důkladný rozbor článků v ústavách postjugoslávských státních útvarů vzniklých po roce 1992. Svou pozornost ovšem věnuje i jiným novodobým sociolingvistickým aktivitám majícím vesměs podobu různě dlouhých a různě pojmenovaných proklamací - od v podstatě celojugoslávské tzv. novosadské dohody (1954) přes chorvatský text Deklaracija o nazivu i položaju hrvatskog književnog jezika (1967), různé deklarace sepsané po roce 1992 (1994 a 1995 o černohorštině, 
1995 a 2007 o chorvatštině, 1998 a 2007 o srbštině a 2002 o bosenštině) až po nejnovější proklamaci nazvanouDeklaracija o zajedničkome jeziku (2017), kterou se kruh hledání symbolicky uzavírá (alespoň pokud jde o tuto formu sociolingvistického projevu).

Následující kapitola South Slavonic Language Paradoxes, University Teaching and Translating Experience (Fragments of the Grotesque Situation) (s. 105-116) se z podstatné části opírá o autorovu vlastní zkušenost jak s výukou inkriminovaných jazyků, tak i s překladatelskou praxí. O to jsou informace v ní obsažené cennější. P. Krejčí v ní klade řadu vtíravých otázek spojených nejen s univerzitní, ale obecně s výukovou praxí na pozadí faktu, že to, co se dříve vyučovalo jako jazyk jeden (tř̌ebaže $\mathrm{v}$ jedné či druhé variantě, ale jak Krejčí ukázal ve druhé kapitole, ani toto rozdělení nebylo vždy striktně dodržováno), by se v současnosti mělo učit - jak vlastně? Odpovědí je více, žádná však není dostatečně uspokojivá. Celý zmatek plynoucí z toho, že co jsme dříve vnímali jako jeden jazyk, se v současnosti prezentuje ve čtyřech formách jako jazyky čtyři, korunuje prŕíklad z překladatelské praxe, který konstrukci čtyř „samostatných“ jazyků kouzlem nechtěného demaskuje a posouvá celou věc do groteskní roviny, kterou P. Krejčí v závěru kapitoly popisuje (s. 115-116).

$\mathrm{V}$ předposlední kapitole nazvané Language Policy in Montenegro (Fragments of the Farcical Situation) (s. 117-131) se autor věnuje rozboru jazykové situace v počtem obyvatel nejmenší postjugoslávské i postsrbochorvatské republice - Černé Hoře. Konstatuje př́tomnost tř́ zásadních proudů, které v současnosti utvářejí černohorský sociolingvistický diskurs: 1. Radical Montenegrists, 2. Pragmatic Montenegrists and 3. Serbian "Neo-Vukovites" (s. 129). Jejich charakteristiku v Summary stručně popisuje takto: „All three groups are based on the certain scientific facts, greater objectivity and scientific maturity, however, is observed only in the second and third group. The first group is under the strong influence of too romantic and nationalist myths" (s. 144). Ve světle této kapitoly je jen škoda, že autor podobným způsobem nezpracoval i jistě neméně zajímavou jazykovou situaci v Bosně a Hercegovině, třebaže poměrně hodně prostoru jí věnuje v kapitole 5 , podkapitole XI (s. 89-95).

Poslední kapitolu Language and Nationalism (Snježana Kordićs Point of View) (s. 133-140) tvoří recenzní příspěvek o knize chorvatské lingvistky Snježany Kordić fezik $i$ nacionalizam (Zagreb 2010). Kniha představuje kritiku jazykové politiky v postjugoslávské, především však chorvatské společnosti vedené mnohdy nacionalistickými představami, které jsou podle autorky v rozporu s vědeckou objektivitou. Tento poslední „fragment“ je určitou symbolickou tečkou za pestrou a z různých aspektů nahližženou složitou problematikou jazykové situace na prostoru bývalého srbochorvatského jazyka (jinak též „centrálního jihoslovanského diasystému“ - jak jej označuje např. D. Brozović - viz pozn. 63 na s. 78). Knihu uzavírá shrnutí (Summary, s. 141-144) a přehled použité literatury (Bibliography, s. 145-152). 
Monografie Pavla Krejčího představuje informovanou a mnohovrstevnatou sondu do problematiky postsrbochorvatské jazykové situace. Autor se opírá o bohatou primární i sekundární literaturu čerpanou především - nikoliv však výhradně $\mathrm{z}$ inkriminovaného prostoru. Není jistě jednoduché orientovat se $\mathrm{v}$ mnohdy protichůdných tvrzeních, přesto se autor knihy snaží - často s určitou nadsázkou (viz některé podtituly kapitol) - tyto nabyté informace evaluovat, klasifikovat a nakonec interpretovat. Práce je o to cennější, že v Česku zatím monografie podobného zaměření a rozsahu nevyšla, a skutečnost, že je psaná anglicky, snad umožní její dosah i mimo hranice země vzniku. Kniha $P$. Krejčího působí velmi svěžím dojmem a přináší zajímavé a syntetizující postřehy a poznatky z minulosti a prrítomnosti bývalé srbochorvatštiny, resp. dnešní srbštiny, chorvatštiny, bosenštiny a černohorštiny.

Sonja Andonova 